\title{
Feasibility Study of Establishing a Granite Aggregate Quarry at Gidan Tagwaye, Dutse Local Government Area of Jigawa State
}

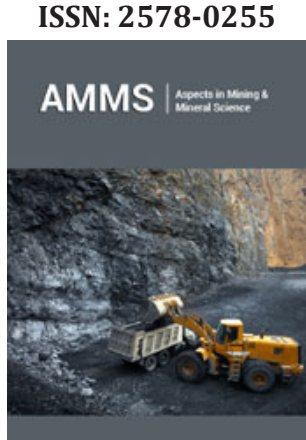

*Corresponding author: Dare Victor Abere, National Metallurgical Development Centre, Jos, Nigeria

Submission: 眥 November 25, 2019

Published: 悔August 21, 2020

Volume 5 - Issue 3

How to cite this article: Abere $\mathrm{DV}^{*}$ Oyatogun GM, Ojo SA, Abubakar UBS, et al. Feasibility Study of Establishing a Granite Aggregate Quarry at Gidan Tagwaye, Dutse Local Government Area of Jigawa State. Aspects Min Miner Sci. 5(3). AMMS. 000613. 2020

DOI: 10.31031/AMMS.2020.05.000613

Copyright@ Abere DV, This article is distributed under the terms of the Creative Commons Attribution 4.0 International License, which permits unrestricted use and redistribution provided that the original author and source are credited.

\author{
Abere $\mathrm{DV}^{1 *}$, Oyatogun $\mathrm{GM}^{2}$, Ojo $\mathrm{SA}^{3}$, Abubakar $\mathrm{UBS}^{1}$, Otebe $\mathrm{SI}^{4}$, Adejo $\mathbf{O H}^{1}$, \\ Gambo $\mathrm{C}^{1}$ and Ayeni TS ${ }^{1}$ \\ ${ }^{1}$ National Metallurgical Development Centre, Nigeria \\ ${ }^{2}$ Department of Materials Science and Engineering, Obafemi Awolowo University, Nigeria \\ ${ }^{3}$ Department of Mechanical Engineering, University of Akron, USA \\ ${ }^{4}$ Department of Dams and Reservoir Operation, Federal Ministry of Water Resources, Nigeria
}

\begin{abstract}
The proposed project will meet the developmental needs of the surrounding community without causing any negative influence on the environment. The establishment of granite quarry in Gidan Tagwaye will pose a positive impact on the socio-economics of the area and lead to overall sustainable development of the region. The study establishes the two major important costs; the capital cost which is put at $\mathrm{N} 456,203,000$ and the operating cost which is put at $\mathrm{N} 64.049,205$. The equipment necessary for the take-off of the quarry and the number of staffs which will be required to run activities in the quarry to make production possible were determined. Furthermore, the cash flow analysis for a period of ten years was carried out at the production rate of $72,533 \mathrm{~m}^{3}$ at the first year and the profit at the tenth year was put as $\mathrm{N} 225,863,959$
\end{abstract}

Keywords: Granite; Quarry; Impact; Cost; Environment

\section{Introduction}

In Nigeria, mining of solid minerals accounts for just $0.2 \%$ of Gross Domestic Product (GDP) as a result of the effect of its huge oil resources [1]. The local mining industry is not fully developed and hence, Nigeria results to importing minerals which it could produce domestically. The right to own mineral resources is held by the government of Nigeria that grants titles to organizations to explore, mine, and sell mineral resources. Nigeria is greatly endowed with vast deposit of mineral resources that can be harnessed towards industrial and technological development to improve the quality of life of the masses [2,3]. Granite is among the minerals deposit in this Nation. Granite is a coarse-grained intrusive igneous rock composed primarily of light-coloured minerals. Crushed granites are small chips of granite, used as a base layer for paving. They are rock-aggregate used in building and general construction [2]. In Southwestern region of Nigeria, the estimated demand in 2008 for granite chipping was 24.2 million tons while the total production was around 18 million tons leaving a supply difference of 6.2 million tons. This translates to an annual market size of over N 48 billion [4]. The supply gap has been discovered to continue to increase as construction activities in the region continue to grow at a faster rate than the increase in production of granites. According to The Netherlands Development Finance Company (FMO) Nigeria's housing deficit to date is 17 million housing units on a total population of over 140 million with virtually no organized mortgage market. Also, infrastructural development most especially with the Federal Government commitment is expected to further increase demand for granite aggregates which are major input in the construction industry [4]. The quarry will be involved in the processing of rocks into granites aggregates including stones and sand dust. The stones output will be of various sizes from $3 / 4$ inch to less than $1 / 2$ inch (stones) and are rich in both quartz and K-feldspar which are standardize sizes in the construction industry. 
In the processes of a mine life span, a feasibility study of the mining project represents an engineering and economic appraisal of commercial viability of the project. The objective of feasibility study is to clarify the basic factors that govern the establishment of the mine process. The conclusion of a feasibility study recommendation is either to continue with the project, delay it for development or abandon it. Furthermore, the study can recommend for a detail work to be carried out on the deposit so as to acquire more information about the deposit. Once all the factors relative to the project have been defined, an attempt is made to quantify as many variables as much as possible in order to arrive at a potential value. The feasibility study or intermediate economic study depend on increasing amount of data pertaining to geological information, plans for mining and processing facilities and initial estimated of project revenues and costs. The Intermediate economic studies of this type will contain information and analysis like project description, geology of the deposit, method of mining and processing transportation, labour requirements, environmental protection, legal consideration economic analysis which includes cost estimates for plant and equipment infrastructure, materials, labour, other factors; market analysis, including production, consumption and product market survey; revenue forecasts base on expected production and mineral prices [5]. Feasibility study also presents detail analysis of all the parameters contained in the intermediate economic studies, along with other important factors relating to political and legal aspects affecting project viability. It is to assess the technical and viability of the project and to assist in making decision on whether to delay, on with or abandon the project development and exploitation [6].

There are two types of expenses which are essential and should be rightly distinguished when preparing feasibility studies of mine. These expenses are the capital and the operating cost. Operating costs are considered to be all day to day incurred in the process of operating the mine. The capital cost or fixed cost are those expenditures made to acquire or develop capital assets, the benefit of which will be derived over several years. The largest portion of capital cost incurred at the initial stages of the project start up, but some capital expenditures are incurred annually throughout the life of the mine. The estimation of cost and capital cost for mining project is extremely difficult and with great care [7]. This work however aims to establish the economic and technical viability of development and exploitation of granite outcrop at Gidan Tagwaye Village, Dutse Local Government area of Jigawa state, and also analyze the capital and operating cost, and methods of extraction to establish if it should be abandoned, delayed, or developed.

\section{Geology of the study area}

The Rock-out-crop at Gidan Tagwaye Village belongs to the older granite of the Northern Nigeria, which is underlain by the Precambrian Basement Complex rock. Porphyritic granite is the most common Basement rocks and intrudes both magnetite and metal sediments. The older granite, pegmatite, aplite, and granodiorite can be found in this area. The older granite occupies the whole Area and the most common of them is the porphyritic granite, granodiorite and aplite are available [8]. Pegmatite is widely distributed throughout the Precambrian basement complex of the Northern Nigeria [4]. Those of Gidan Tagwaye are part of the pegmatite Northern Nigeria, they are extremely coarse Igneous bodies closely weathered and is spaced to large masses plutonic rocks, they are found in veins and dykes traversing the granular Igneous rock, but most commonly extends out from it into the surrounding country rock which occurs in scattered form. They consist of quartz. Feldspar and Muscovite [9].

It also forms part of the crystalline Basement Complex rock and it is the most widely spread rock in this area. They have elliptical to elongated shape, which is seen to be related to the tersian emplacement. It is made up of feldspar with potash. Feldspar dominating plagioclase quartz, biotite, and small percentage of other minerals. The feldspar and quartz are predominant. The bonds between the mineral and grain are rigid and elastic [4]. Two textures may be observed, even grain or granular or granite texture. In porphirtic texture, phenocryst features or geologic structures; that is, the mutual setting of extremely similar parts of a rock which indicates the way rocks respond the application of deformation forces and the structures resulting from the deformation. Joint field and foliation like structure are present in GidanTagwaye coarse porphyritic granite rock but less degree pegmatite veins can be seen here and forming sets of veins called joints system in two opposite directions [4].

\section{Location and accessibility of the project site}

Gidan Tagwaye is about twenty (20) kilometer from Dutse, outskirt of Dutse Local Government Area of the Jigawa State. The project site is located in Gidan Tagwaye, on the longitude of $9^{\circ} 22^{\prime}$ and the latitude of $11^{\circ} 45^{\prime}$, in Dutse Local Government Area, of Jigawa State, with Area coverage of about thirty hectares. It is accessible from Shuwarin along Kano-Maiduguri Express Road leads to project site. The distance of rocks A and B to the closest settlements are $150.225 \mathrm{~m}$ and $300.220 \mathrm{~m}$ respectively. Also, the distance of rock $\mathrm{A}$ and $B$ to the major road are $500.088 \mathrm{~m}$ and $603.55 \mathrm{~m}$ respectively.

\section{Factors influencing the setting up a granite quarry and of quarrying}

These factors that lead to setting up a granite quarry are pertinent and variable physical and financial features considered and analyzed when intending to set up a granite quarry [10]. The significance of each variable will be a function of setting up a granite quarry. These factors include:

a. Nature and orientation

b. Location of the granite deposit

c. The social factors 


\section{d. Demand and supply (Economic factors)}

Nature and orientation: The nature of a granite deposit which includes the rock types and physical properties which are unique, such as shape, size, thermal stability, hardness, co-efficient of expansion, porosity, and permeability. Also, the chemical properties, which compose of minerals such as Alkaline Feldspar, quartz and mica. If all these properties and minerals are found in the proper proportion in a granite deposit, then deposit is suitable for extraction and it has an economic value.

The location of the granite deposit: This factor is very important, its distance to town, where it serves as a raw material for construction, the condition of roads and suitability for the vehicles to access the road where the deposit is found is a function of cost. This invariably means its distance from town and lack of good accessible road will directly increase the cost of transportation to the town or point of use. And also affect the cost of production, the selling price and revenue at the end production.

The social factor: The availability of labour and the type of labour need and available at a point in time is very important. The availability of skilled labour to mount the different machines and handle them properly and correctly will directly affect the rate of productivity in the site, which will affect maximization of profit.

Demand and Supply: In fact, this factor is very important because no mining work will be carried our if the market condition is not well established. The marketability of the product should be known in terms specification, the purchasers and purchase levels. The expected price and trends, competitive cost levels and sales characteristics.

Granite is a rock deposit which mostly finds its origin particularly to igneous rock, but evidence has shown that some granite rocks are found to originate from metamorphism. The petrologists regard granite as a visible crystalline rock with interlocking texture which is composed essentially of some important minerals such as: Alkaline Feldspar, mica and quartz [4]. Granites that find their origin to igneous rock are generated at the convergent plates boundaries where the oceanic lithosphere (the outer layer of the earth crust and upper mantle) is sub-ducted so that its edge is below the edge of the continental plate or another oceanic plate. The formation of granite is often envisioned as two stages of process which include;

a. Partial melting of lower crust

b. Sub-ducted oceanic material to form magma of andesitic composition [4].

Due to the presence of these minerals, granite was found to be of economic importance. Granite is used for construction of roads and bridges, buildings, dam, drainages, and for making glasses and tiles for both interior and exterior decorations [2,3]. Quarrying is a method of surface mining which involves drilling and blasting op- erations or activities. This method of surface mining is used in the extraction of metallic and non-metallic ore or minerals deposit that are of economic viability. The example of metallic ore minerals in which quarrying method is used to extract is iron ore (Hematite, $\mathrm{Fe}_{2} \mathrm{O}_{3}$ ), while for the non-metallic minerals are granite and coal etc. Quarrying is the most expensive surface mining and is highly selective, and also sometimes on a small-scale production depending on size of the mine and the deposit [11]. Quarrying is divided into two methods namely;

\section{a. Manual or artisanal method of quarrying \\ b. Mechanized method of quarrying}

The artisanal technique of quarrying is characterized with the use of simple and local tools and with a low rate of production. The method usually has no direction and quarry face, the work is done from exposed face and where cracks exist. The granite rock is weakened by using fire wood or used tyres which are Heaped on the granite rock and are burnt to heat up the rock to a high temperature and water are poured on the heated part of the rock thereby causing an extreme and sudden change in temperature and a resultant crack in the rock. Then sledge hammers are used to break the stone into sizes. The bigger boulders are further broken with the sledge hammers. In essence, man power is used in die manual method of quarrying [11]. In the mechanized method of quarrying, the production is done on a large scale. Virtually, all the operations are been mechanized and are operated by skilled labours. This method of quarrying is capital intensive, there the quarry has a direction, a face and its operations are well organized. This method involves the use of drilling equipment to create short holes or blast holes for the placement of explosives for the purpose of disintegrating the rock using plan detonators or electric detonators. Then the boulders are re-blasted after holes have been placed using secondary drillers, such as hand held drill (Jack-hammer). The broken granite is been loaded into the truck trailer and is transported to the crusher. Then the crusher is used to crush the granite into different sizes [11].

\section{Method}

\section{Interview}

The interview involved verbal interactions with the villagers and the district head about the history of the outcrop. Information was sourced about the ownership of the land, and its legal status to find out whether there had been any previous workings on the outcrop. Information was also sourced from mining companies on maintenance, and handling of mining equipment and the prices of the mining equipment as well as the factors that influence the selection of equipment and establishing granite quarry.

\section{Observation at the site}

The site of the outcrop at GidanTagwaye, Dutse Local Government of Jigawa State was carefully studied in order to assess the outcrop and the surroundings; to design the mine or quarry lay out 
and their physical conditions. The site was also studied to enable good planning of the quarry site and situating the crusher plant at a very good and convenient place.

\section{Valuation of the outcrops}

The valuation of the outcrops involved fieldwork and survey to establish the tonnage and reserves of the outcrops based on data collected or obtained during the survey and fieldwork. These data were used to calculate the areas, volumes and then the tonnage of the outcrops [12].

\section{Environmental Impact Assessments (EIA)}

Since quarrying activities generally pose adverse effects on the environment, the EIA was conducted, and measures were taking to mitigate the effects.

\section{Economic evaluation}

The information on the cash flow rate, time value for money and mining design plan work were determined.

\section{Findings and Discussions}

\section{Presentation of results}

The volume and then the tonnage of the outcrops can be calculated when the Area has been obtained. The volume computations and tonnage of Area showed below (Table 1).

Table 1: The volume computations and tonnage of area.

\begin{tabular}{|c|c|}
\hline \multicolumn{2}{|c|}{ Grid Volume Computations of Rock A } \\
\hline \multicolumn{2}{|c|}{ Upper Surface } \\
\hline Grid size: & 100 rowsx83 columns \\
\hline $\mathrm{X}$ minimum & 352177 \\
\hline X maximum & 352397 \\
\hline X spacing & 2.463414634146 \\
\hline Y minimum & 1155101 \\
\hline Y maximum & 1155344 \\
\hline Y spacing & 2.4545454545455 \\
\hline \multicolumn{2}{|c|}{ Difference in Elevation } \\
\hline $\mathrm{Z}$ minimum & $675.0656565509 \mathrm{~m}$ \\
\hline $\mathrm{Z}$ maximum & $702.12498938738 m$ \\
\hline \multicolumn{2}{|l|}{ Lower Surface } \\
\hline Level surface defined by Z & 675.0656565509 \\
\hline \multicolumn{2}{|c|}{ Volume } \\
\hline 2 scale factor & 1 \\
\hline Total volume by & $1355094.360 \mathrm{~m}^{3}$ \\
\hline \multicolumn{2}{|c|}{ Areas } \\
\hline Positive planner Area (cut) & 49086 \\
\hline Negative planner Area (fill) & 0 \\
\hline Blanked planner Area & 0 \\
\hline Total planner Area & 49086 \\
\hline \multicolumn{2}{|c|}{ Surface Areas } \\
\hline Positive surface Area (cut) & 50188.680316478 \\
\hline Negative surface Area (fill) & 0 \\
\hline Tonnage & 3658754.8 tones \\
\hline \multicolumn{2}{|c|}{ Grid Volume Computations of Rock B } \\
\hline \multicolumn{2}{|c|}{ Upper Surface } \\
\hline Grid size: & 72 rowsx 100 columns \\
\hline $\mathrm{X}$ minimum & 352091.2689 \\
\hline X maximum & 352329.538 \\
\hline X spacing & 2.4067585858583 \\
\hline Y minimum & 1155425 \\
\hline Y maximum & 55597 \\
\hline
\end{tabular}




\begin{tabular}{|c|c|}
\hline Y spacing & 2.4225352112676 \\
\hline \multicolumn{2}{|c|}{ Difference in Elevation } \\
\hline $\mathrm{Z}$ minimum & 678.24295339684 \\
\hline $\mathrm{Z}$ maximum & 695.82042175472 \\
\hline \multicolumn{2}{|c|}{ Lower Surface } \\
\hline Level surface defined be 2 & 678.24295339684 \\
\hline \multicolumn{2}{|c|}{ Volume } \\
\hline Z scale factor & 1 \\
\hline Total Volume by & $746016.9 \mathrm{~m}^{3}$ \\
\hline \multicolumn{2}{|c|}{ Areas } \\
\hline \multicolumn{2}{|l|}{ Planner Areas } \\
\hline Positive planner Area (cut) & 40982.28519999 \\
\hline Negative planners Area (fill) & 0 \\
\hline Blanked planner Area & 0 \\
\hline Total planner Area & 40982.285199996 \\
\hline \multicolumn{2}{|c|}{ Surface Areas } \\
\hline Positive surface Area (cut) & 41445.383869324 \\
\hline Negative surface Area (fill) & 0 \\
\hline Tonnage & $2,014,245.6$ tones \\
\hline
\end{tabular}

\section{Description of outcrops}

The rocks are located at Gidan Tagwaye through Shuwarin Town in Dutse Local Government Area of Jigawa State by the side of the express road leading from Kano to Maiduguri, and also the distance of rock A and B to the major road are $500.088 \mathrm{~m}$ and $603.55 \mathrm{~m}$ respectively. The elevation of rock $A$ is $781 \mathrm{~m}$ and rock $B$ is $774 \mathrm{~m}$ above sea level. The rocks have quartz veins cutting through them. Also, there are cracks and faults featuring on the rocks and are more Prominent on rock B. (Figures 1-7) show different locations on the rocks and site.
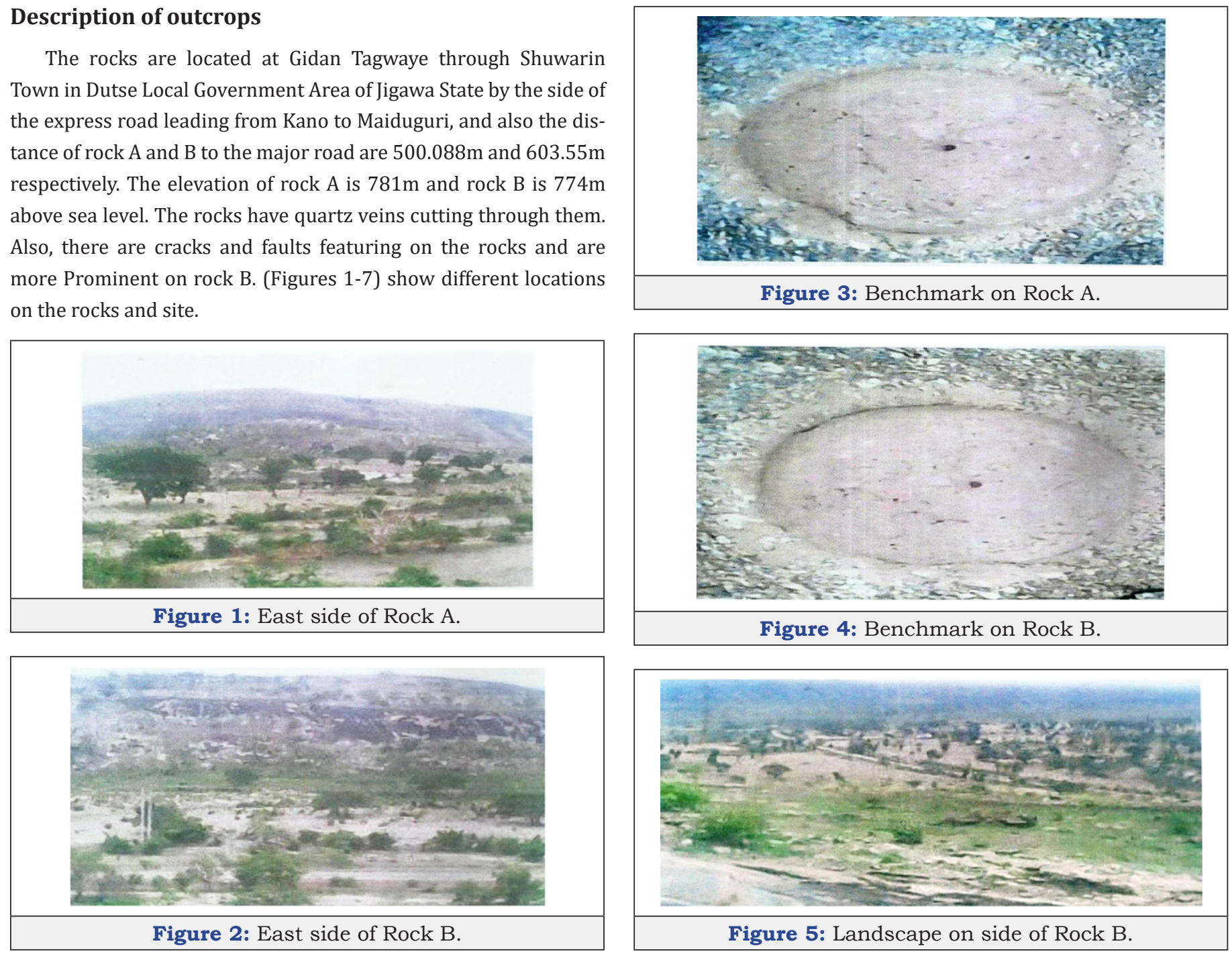


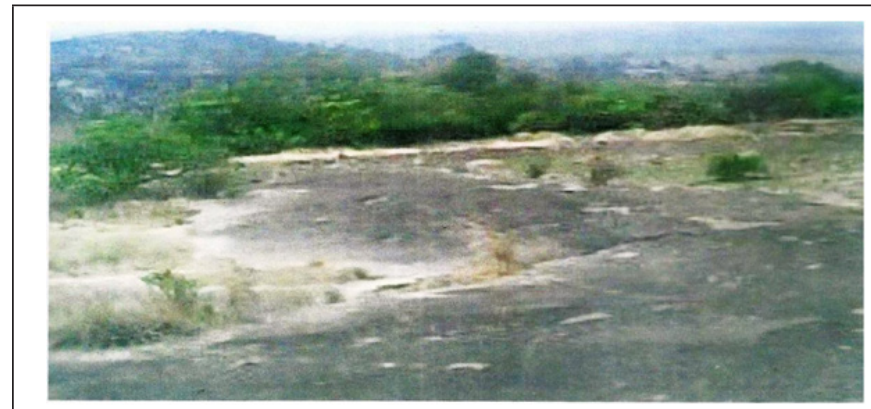

Figure 6: Cracks and fissures on Rock A.

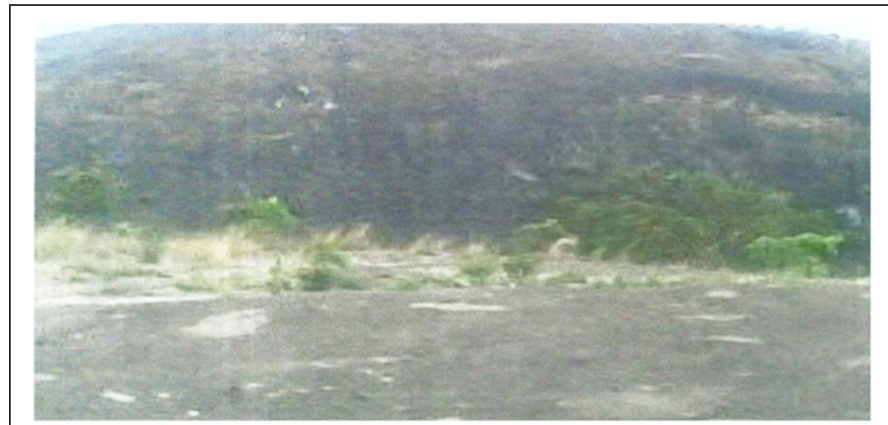

Figure 7: Picture of Rock A taken from Rock B.

\section{Quarry layout}

The quarry layout is the location and position of the surface plants and the access road into the quarry. The diagram below shows the proposed quarry layout of the outcrops, this is otherwise known as the design of the mine site. The layout of the quarry is shown in Figure 8.

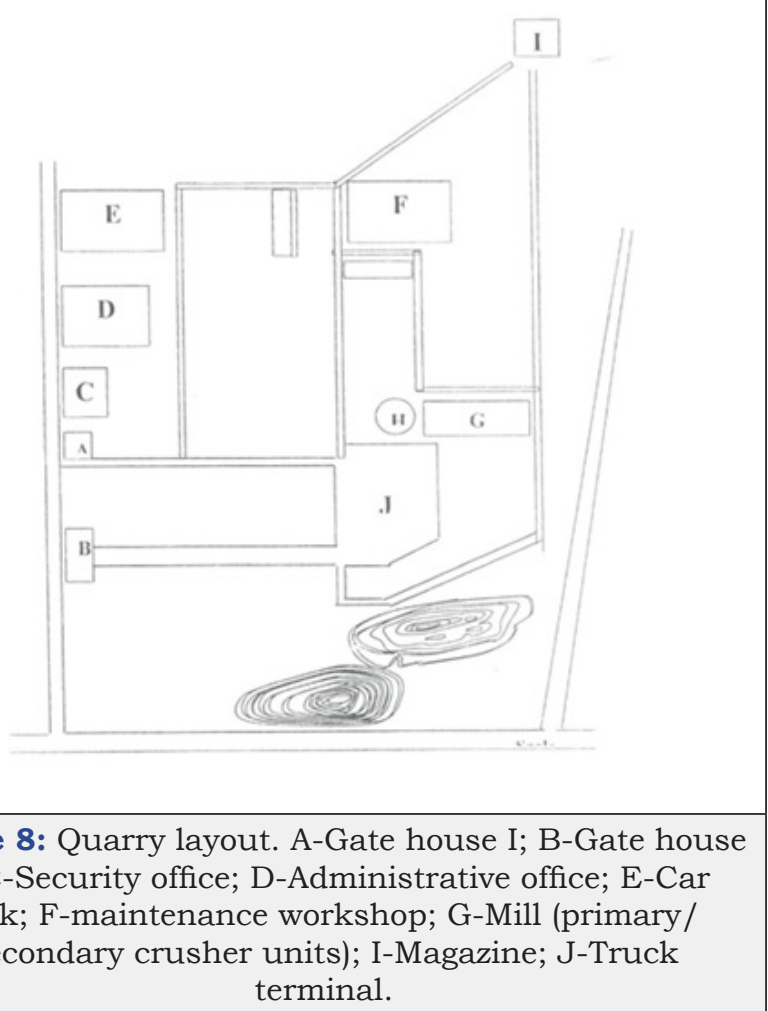

\section{Quarry services}

These are infrastructural facilities and social amenities that will enter the quarry activities in the site, below are list of this services required.
a. Water supply
b. Power supply (Generating set)
c. Power Holding Company of Nigeria (PHCN)
d. Communication
e. First Aid facilities

\section{Legal and administrative framework}

The legal and administrative framework is concerned with the regulation sand legislation of the country in application, processing and obtaining a mineral title. This involves the Mining Law governing the mining activities and mineral title in a particular country. To acquire a quarry lease, there are some processes and procedures that have to be followed. First, obtain application form A-5, from the Mining Cadastre Office in Ministry of Mines and Steel Development. Then the form is carefully and dully filled with all necessary information demanded for well stated $[13,14]$. The form must be submitted in triplicate back to the Mining Cadastre office and the applicant of the quarry lease making a payment of non-refundable processing fee of N100,000.00. When the applicant pays the processing fee on submission of the application form, the submitted application shall be assigned with an identifying code and registered with the date, hour and minute stated in the priority register dully signed and a copy is given to the applicant as application certificate. The time that it will take for processing the quarry lease is not later than forty-five days of filling application as stated in [10]. Also, the overall area of the quarry lease that can be applied for should not exceed five square kilometers [10]. When the mineral license is granted applicant shall be informed and given fourteen days within which to pay the Annual service fee on the numbers applied for per cadastre unit and collect the license few days after payment. But, if the applicant does not collect the license within fourteen days of notification, the license shall be automatically cancelled while provisional plotting will be deleted from the cadastre maps and shall be sanctioned from applying for the same area or portion of it during the next three months. Also, some requirements of granting of Mineral title according to Section 54 sub-section 1 of Nigerian Minerals and Mining Act, 2007 states that; proof of sufficient working capital for the exploration or Mining of the area applied for and of technical competence to carry on the proposed exploration or Mining operation as prescribed in the regulation. The quarry lease when granted is valid for the period of five years and is renewable. And it is advisable that the processing of renewal must be made within the three months before the expiring date of the lease [10]. 


\section{Environmental Impact Assessment (EIA)}

Planning must account for both environmental protections, beginning as early as the initial exploration, and for reclamation. It is critical that lining alleviate or mitigate potential impacts of mining for two key reasons which are mentioned below $[15,16]$.

a. The cost of environmental protection is minimized by incorporating it into the initial design rather than performing remedial measures to compensate for design deficiencies.

b. Negative publicity or poor public relations may have severe economic consequences.

From the start of the planning process, adequate consideration will be given to regulatory affairs. The cost of compliance may be significantly reduced when taken into account in the design or planning process, in a pro-active manner, rather than being addressed on an ad-hoc basic as problem develops or enforcement actions occur. The environmental impact assessment regulations are found in the section; 119 of [15]. Where the holder of the quarry lease has to ensure compliance with the provision of the section, one of its provision is that an environmental impact assessment statement approved by the Federal Ministry of Environment in respect of the exploration or mining operations to be conducted within the mineral titles area. Some of the environmental impact caused by quarrying operation are; aesthesis, air quality (dust and pollutants), vibration and flying rocks [5]. Also, some of the positive impact of quarrying are creation of employment opportunity, source of income, social amenities for the local people within the area.

\section{Environmental rehabilitation regulation}

The mine plan must include all the technical measures necessary to handle all the environmental problems from initial data gathering to the mine closure and reclamation of the disturbed surface area. Reclamation plans should include the following concerns; drainage control, preservation of top soil, segregation of waste material, erosion and sediment control, control of fugitive dust, re-grading and restoration of waste and mine areas. The plan must also consider the effect of mine subsidence, vibration and impact on the surface water and ground water. The environmental rehabilitation regulation is founded in section 120 of [15]. Some of the provisions in this section are;

a. The mineral title holder in the program of environmental protection and rehabilitation under the provision of the act shall provide for specific rehabilitation and reclamation actions, inspections, and annual reports.

b. A reasonable estimate of the total cost of rehabilitation.

c. Cost estimate for each specific rehabilitation and reclamation action.

d. A timetable of the orderly and efficient rehabilitation and reclamation of the mineral title area to a safe and environmental sound condition suitable for future economic development or recreation use.

These provisions are found in the sub-section 1 of section 120 of [15].

\section{Facilities for environmental management}

Generally building stone quarrying is expected to cause air pollution leading to breathing problems. Activities like drilling, blasting, excavation and movement of heavy vehicles cause dust and worsen air pollution in addition to noise pollution. For mitigating the adverse impacts of the above, suitable control measures are planned and they include: For activities like drilling, dust suppression etc. water will be required. Also, for meeting the drinking and sanitary needs of the employees/workers, water will be required. For the disposal of the sanitary wastewater (sewage), septic tank with soak pit will be constructed at a suitable place, within close vicinity of the proposed area. To take care of the occupational health and safety of workers at site, engaged at strategic locations/dust generation points like loading and unloading points, dust masks will be provided. Dust masks will prevent inhalation of Respirable Particulate Matter and hence, minimize the hazard of lung diseases and other respiratory disorders. Regular health monitoring of workers will be examined.

The solid waste that might be generated from the proposed activity will be mainly from the excavation process. This will be in the form of flakes or irregular shape. This will be collected and broken into pieces and can be sold as aggregates for civil works, because of its hard nature. Most of the area is of sheet rock and the present proposed work is confined to sheet rocks. Less than $5 \%$ of materials are being treated as waste in this area. The rejected waste material will be stacked in the Waste Dump. A JCB will be used to remove the over burden from the surface. When the dump reaches optimum height, suitable greenery will be grown on this dump to stabilize them. In addition, as a proactive measure, the following activities will be initiated:

a. The rainwater accumulating in the work area will be collected and will be drained-out to the downstream properly with guide drains, so that it can be utilized by the downstream fields for their agriculture and allied purposes.

b. To avoid soil erosion, rainwater entering into the mine pit, carryover of the material with rainwater, suitable garland drains will be provided all along the active mine area.

\section{Economic evaluation}

Capital cost: The capital cost is the point where huge and larger part of investment of the company is made and this includes the; cost of equipment (Table 2), cost of infrastructure (Table 3), cost of furniture and cost of vehicles (Table 4). The capital cost is summarized in (Table 5). 
Table 2: Cost of equipment.

\begin{tabular}{|c|c|c|c|c|c|}
\hline S/No & Equipment & Quantity & Model/Type & Cost(N) (x1000) & Manpower Requirement \\
\hline 1 & Bulldozer & 1 & Cat 824C & 43.596 & 1 \\
\hline 2 & Wagon drill & 1 & Atlascopco Roc 442 & 15 & 1 \\
\hline 3 & Compressor & 1 & KaeserAso 25 & 2.373 & 2 \\
\hline 4 & Jack hammer & 2 & C.p Canada & 0.43 & 3 \\
\hline 5 & Truck Trailer & 3 & Cat 725 & 211.104 & 1 \\
\hline 6 & Jaw Crusher & 1 & $200 \mathrm{t} / \mathrm{hr}$ & 58 & 1 \\
\hline 7 & Cone crusher & 1 & $200 \mathrm{t} / \mathrm{hr}$ & 25 & 1.5 \\
\hline 8 & Impact hammer & 1 & & 26.7 & 1 \\
\hline 9 & Front-end loader & 1 & & 100 & 1 \\
\hline 10 & Miscellaneous & & $914 \mathrm{G}$ & 483.703 & \\
\hline
\end{tabular}

Table 3: Cost Infrastructure.

\begin{tabular}{|c|c|}
\hline Description & Cost (N) \\
\hline Administrative block & $15,000,000$ \\
\hline Maintenance workshop & $5,000,000$ \\
\hline Security post & $1,500,000$ \\
\hline Magazine & $2,500,000$ \\
\hline Borehole and overhead tank & $2,000,000$ \\
\hline $\begin{array}{c}\text { Alternative power } \\
\text { supply(generator) }\end{array}$ & $15,000,000$ \\
\hline Miscellaneous & $1,000,000$ \\
\hline Total & $42,000,000$ \\
\hline
\end{tabular}

Table 4: Cost of vehicles.

\begin{tabular}{|c|c|c|}
\hline S/ No & Description & Cost (U) \\
\hline 1 & Administrative car & $3,500,000$ \\
\hline 2 & Explosive van & $6,000,000$ \\
\hline 3 & Staff bus & $10,000,000$ \\
\hline 4 & Pickup van (Hilux) & $5,000,000$ \\
\hline 5 & Miscellaneous & $1,000,000$ \\
\hline & Total & $34,500,000$ \\
\hline
\end{tabular}

Table 5: The summary of capital cost.

\begin{tabular}{|c|c|c|}
\hline Description & Cost (U) & Percentage (\%) \\
\hline Cost of equipment & $483,703,000$ & 84.11 \\
\hline Cost of infrastructure & $41,000,000$ & 8.99 \\
\hline Cost of furniture & $7,000,000$ & 1.53 \\
\hline Cost of vehicles & $34,500,000$ & 5.26 \\
\hline Miscellaneous & $3,000,000$ & 0.8 \\
\hline Total & $856,203,000$ & 100 \\
\hline
\end{tabular}

Cost of infrastructure: These are structures that will be constructed on the mine field for the smooth running of the quarry. The structures include the administrative block and others.

Cost of furniture: The estimated cost of furnishing the administrative block is given to be $\mathrm{N} 7,000,000.00$.

Operating cost: The operating cost involves the daily cost of running the quarry and total expenditure of production. It is illustrated in (Tables 6-8).

Table 6: Estimate cost of labour.

\begin{tabular}{|c|c|c|c|}
\hline Staff & Number/Rate & Monthly Salary (N) & Total Salary per Annum (N) \\
\hline Quarry Manager & 1 & 80,000 & 960,000 \\
\hline Quarry supervisor & 1 & 60,000 & 720,000 \\
\hline Accountant/Sale manager & 1 & 40,000 & 480,000 \\
\hline Bulldozer operator & 1 & 30,000 & 360,000 \\
\hline Dump truck operator & 3 & 90,000 & $1,080,000$ \\
\hline Pay-loader operator & 1 & 30,000 & 360,000 \\
\hline Storekeeper & 1 & 30,000 & 360,000 \\
\hline Driller/Blaster & 3 & 90,000 & $1,080,000$ \\
\hline Drivers & 4 & 120,000 & $1,440,000$ \\
\hline Security guards & 4 & 120,000 & $1,440,000$ \\
\hline Maintenance officers & 3 & 90,000 & $1,080,000$ \\
\hline Secretary/personal assistant & 1 & 30,000 & 360,000 \\
\hline
\end{tabular}




\begin{tabular}{|c|c|c|c|}
\hline Messenger & 1 & 15,000 & 180,000 \\
\hline Crusher operators & 4 & 80,000 & 960,000 \\
\hline Miscellaneous & & & 500,000 \\
\hline Total & 26 & 785,000 & $9,920,000$ \\
\hline
\end{tabular}

Table 7: Estimated cost of protective clothing and safety facilities.

\begin{tabular}{|c|c|c|c|}
\hline Type & Quantity & Unity Price (N) & Bulk Price (£Q \\
\hline Safety helmet & 30 & 1,700 & 51,000 \\
\hline Safety boot & 30 & 2,500 & 75,000 \\
\hline Hand glove & 30 & 200 & 6,000 \\
\hline Dust mask & 30 & 500 & 15,000 \\
\hline Earmuff & 30 & 400 & 12,000 \\
\hline Miscellaneous & - & - & 10,000 \\
\hline Total & & & 169,000 \\
\hline
\end{tabular}

Table 8: Estimated cost of drilling rods and accessories.

\begin{tabular}{|c|c|c|c|}
\hline Description/Types & Quantity & Unitary Price (H) & Bulk Price (H) \\
\hline Bits & 12 & 27,000 & 324,000 \\
\hline Extension rod & 9 & 45,000 & 405,000 \\
\hline Coupling sleeve & 3 & 8,500 & 25,500 \\
\hline Shank adaptor & 2 & 27,000 & 54,000 \\
\hline Drilling string & 10 & 17,000 & 170,000 \\
\hline Drilling horses & 2 & 45,000 & 90,000 \\
\hline Sledge hammer & 3 & 2,000 & 6,000 \\
\hline Wheel barrow & 2 & 10,000 & 20,000 \\
\hline Miscellaneous & & & 12,000 \\
\hline Total & & & $1,106,500$ \\
\hline
\end{tabular}

Estimated cost of consumable: This cost involves mostly the administrative cost and cost of running the office. The cost of administrative running is estimated to be $\mathrm{N} 250,000$ per annum. The estimated cost of explosive consumptions is presented in (Table 9).

Table 9: Estimated cost of explosive consumptions.

\begin{tabular}{|c|c|c|c|c|}
\hline Type & Description & Unity Price & Bulk Price & Cost per Annum \\
\hline Detonating cord L & $1000 \mathrm{~m}$ per month & 60 per meter & 60,000 & 720,000 \\
\hline Plain detonator & 8 pieces per month & 120 pieces per month & 960 & 11,520 \\
\hline Safety fuse & $20 \mathrm{~m}$ per month & 200 per meter & 4,000 & 48,000 \\
\hline Ammonia nitrate & 15 bags per month & 3000 per bag & 45,000 & 540,000 \\
\hline Relay delay & 144 per month & 250 per pieces & 36,000 & 270,000 \\
\hline Dynamite & 2112 carton & 9000 per & 22,500 & 432,000 \\
\hline Bomb squad & Per month & Carton & 40,000 & 50,000 \\
\hline Police escort & 4 times per & 10,000 per trip & \\
\hline Miscellaneous & Month & 10,000 per trip & 45,000 & 500,000 \\
\hline Total & & & & $3,650,520$ \\
\hline
\end{tabular}

Estimated cost of fueling and lubrication: The cost of fueling and lubrication, repairs and maintenance is assumed to be $3 \%$ of the original cost of equipment. Then cost of fueling and lubrication is estimated as the Cost of equipment $\mathrm{x} 0.03$ [7].

\section{$383,703,000 \times 0.02=\mathrm{N} 11,511,090.00 \mathrm{k}$}

The estimated cost of acquisition of title is shown in (Table 10).

Table 10: Estimated cost of acquisition of title.

\begin{tabular}{|c|c|}
\hline Description & Cost (N) \\
\hline Application for quarry lease & 60,000 \\
\hline Application for blasting certificate & 10,000 \\
\hline Certificate of occupancy (c of o) & 150,000 \\
\hline
\end{tabular}

\begin{tabular}{|c|c|}
\hline Compensation to village head & 100,000 \\
\hline Miscellaneous & 50,000 \\
\hline Total & 370,000 \\
\hline
\end{tabular}

Estimated cost of utilities and services: The cost of utilities and services involves the cost of power supply from the national grid, medical cost and miscellaneous which is estimated to be $\mathrm{N}$ $143,000,000.00 \mathrm{k}$

Estimated cost of rents and royalties: The surface rent and royalty payable to both state and federal government annually are estimated to be $\mathrm{N} 150,000.00$. Royalty which is charge at the rate of hours per ton, where the annual production is $72,533.33$ tons, 
Royalties is $72,533.33 \times 5$

$=\mathrm{N} 2,304,000.00$ per annum.

Therefore, the total rent and royalties is equal to $\mathrm{N} 2,304,000+$ N $150,000=$ N 2,454,000.00

Depreciation of equipment: The depreciation of all the equipment in the Mine before they are been replaced. With a good maintenance, it is assumed that the life span of the equipment is fifteen years. Then the depreciation of the equipment per annum can be calculated using the formula by [7] given below:

$$
\text { Depreciation }=\frac{\text { Total } \cos \text { tofequipment }- \text { ScrapValue }}{\text { Lifespanofequipment }}
$$

Assuming the life span of equipment is fifteen years, then the depreciation is calculated below.

$$
\text { Depreciation }=\frac{383,703,000-15,000,000}{15}
$$

$=\mathrm{N} 24,580,200$

Depreciation of infrastructures: Taking the depreciation on infrastructures to be $10 \%$ of its original value per annum [15]. Therefore, the depreciation for the first year is;

Depreciation $=24,580,200 \times 0.1$

$$
=\mathrm{N} 24,580,020
$$

Insurance premium: Insurance premium involves insuring the major equipment for Mining, the vehicles in the Mine against accident, collision and overturning, theft, burglary, damage during transit (Tables 11 \& 12). And also, the buildings should be insured against fire accidents and collapsing. The tariffs rate is as follows.

Table 11: Insurance premium per annum.

\begin{tabular}{|c|c|c|}
\hline Description & Cost (N) & Percentage $(\%)$ \\
\hline Cost of labour & $9,420,000.00$ & 14.71 \\
\hline Cost of protective clothing and safety facilities & $159,000.00$ & 0.25 \\
\hline Cost of drilling rods and accessories & $1,094,500.00$ & 1.71 \\
\hline Cost of explosive & $2,510,520.00$ & 3.92 \\
\hline Cost of fueling and lubrication & $11,511,090.00$ & 17.97 \\
\hline Cost of consumables & $250,000.00$ & 0.39 \\
\hline Cost of acquisition of title & $320,000.00$ & 0.5 \\
\hline Cost of Utilities and services & $3,000,000.00$ & 4.68 \\
\hline Cost of rents and royalties & $2,454,000.00$ & 3.83 \\
\hline Depreciation of equipment & $24,580,200.00$ & 37.47 \\
\hline Depreciation of infrastructure & $2,400,000.00$ & 3.75 \\
\hline Insurance premium & $6,347,940.00$ & 9.91 \\
\hline Total & $64,047,250.00$ & 100 \\
\hline
\end{tabular}

\begin{tabular}{|c|c|}
\hline Item/Structure & Premium per Annum(N) \\
\hline Equipment & $3,837,190.00$ \\
\hline Motor vehicles & $2,450,000.00$ \\
\hline Administrative block & $33,750.00$ \\
\hline Maintenance block & $15,000.00$ \\
\hline Security block & $4,500.00$ \\
\hline Office furniture & $7,500.00$ \\
\hline Total & $6,347,940.00$ \\
\hline
\end{tabular}

Table 12: Summary of operating cost.

a. The equipment that are to be used only in quarry for excavating, loading and haulage purposes, the premium charged is $\$ 4200$ for the first year N4000.00 of the value of the equipment, while for the part there-off if is charged at the rate of $1 \%$ of the original value.

b. The premium for the infrastructure against fire accidents are
i. Administrative blocks
ii. Maintenance workshop
iii. Security block
iv. Office furniture

$=0.225 \%$ of value

$=0.3 \%$ of value

$=0.3 \%$ of value

$=0.3 \%$ of value

\section{v. Magazine}

$=0.3 \%$ of value

Using these charges given above, the various insurance premiums are calculated as shown in the (Table 13).

Annual income 1: Unit Cost of Production

Annual cost of working=N1464, 049,250.00 (operating cost)

Annual production $=85,333.33 \mathrm{~m}^{3}$

Unit cost of production= $($ Annual cost of working $) /($ Annual cost of production)

Where annual production is obtained by

Production per hour $=74 \mathrm{~m}^{3}$ 
Production per shift $=8 \times 74=593 \mathrm{~m}^{3}$

Production per week assume three working days $=3 \times 593=\mathrm{l}$, $779 \mathrm{~m} 3$ Production per month $=4 \times 1,779=7,116 \mathrm{~m}^{3}$

Production annually $=12 \times 7,116=85,333.33 \mathrm{~m}^{3}$

It was assumed that the Crusher efficiency is $85 \%$, and then annual production is $72,533.33 \mathrm{~m}^{3}$

$$
\text { Unitcos tof production }=\frac{64,049,250,00}{72,533,33}=N 883.00
$$

Annual income 2: The present selling price of one cubic meter of granite aggregate is $\mathrm{N} 45,500$ per meter cube [17].

Annual income=selling price per meter cube $\mathrm{x}$ Annual production

$$
\begin{aligned}
& =45,500 \times 72,533.33 \\
& =N 3300,266,515.00 \mathrm{k}
\end{aligned}
$$

Annual gross profit: In computing the annual gross profit, it involves finding the difference between the sum of the operating cost and annual cost of reclamation with the annual income obtained from sales of the granite aggregate. In this work it is assumed that $1 \%$ of the total annual income will be used for the environmental reclamation.

The environmental reclamation fund $=0.1 \times 398,933,315$

$$
=\mathrm{N} 3,989333.15 \mathrm{k}
$$

Then the annual gross profit is;

$\begin{array}{ll}\mathrm{N} & \mathrm{k} \\ 398,933,315 . & 00 \\ -64,049,250 . & 00 \\ -3,989,333 . & 15 \\ 330,894,716.85 & \end{array}$

Cash flow analysis 1: Project Income for the 10 Years

The peculiarity with mining project is that the production rate does not reach optimum at the first year of production. And in quarry operation the production level is usually met at least $75 \%$ of the total intended rate of production for the first few years. The intended production of granite aggregate in this project is 200 ton per hour. (Table 13) shows the projected income for ten years.

Table 13: Projected income for 10 years.

\begin{tabular}{|c|c|c|c|c|c|}
\hline Year & Annual Production $\mathbf{( m}^{\mathbf{3}} \mathbf{)}$ & Income Annually (N) & Average Operating Cost (N) & Reclamation 1\% (N) & Net Income (N) \\
\hline 1 & $72,533.33$ & $398,933,315.15$ & $64,049,250.00$ & $3,989,333.15$ & $330.894,716$ \\
\hline 2 & 69.973 & $384.851,500.00$ & $64,049,250.00$ & $3,848,515,00$ & $316,953,735$ \\
\hline 3 & 67,413 & $370.771,500.00$ & $64,049,250.00$ & $3,707,715.00$ & $302,954,535$ \\
\hline 4 & 64.853 & $356.691,500.00$ & $64,049,250.00$ & $3,566,915.00$ & $289,075,335$ \\
\hline 5 & 62,293 & $342,611,500.00$ & $64,049,250.00$ & $3,426,115.00$ & $275,136,135$ \\
\hline 6 & 59.933 & $329,631,500.00$ & $64.049,250.00$ & $3,296,315.00$ & $262,285,935$ \\
\hline 7 & 57,173 & $314.451,500.00$ & $64,049.250 .00$ & $3,144,150.00$ & $247,250,100$ \\
\hline 8 & 55,466 & $305,063,000.00$ & $64,049,250.00$ & $3,050,630.00$ & $237,963,120$ \\
\hline 9 & 55,466 & $305,063,000.00$ & $64,049,250.00$ & $3,050,630.00$ & $237,963,120$ \\
\hline 10 & 55,466 & $305,063,000.00$ & 64049.250 .00 & $3,050,630.00$ & $237,963,120$ \\
\hline
\end{tabular}

Cash flow analysis: The (Table 14) above shows the net income at the end of each year which is a positive income but the interest on the money loaned or from investors are not being removed yet which should be accounted for from the net profit. Assumed the sum of $£ 4500$ million was loaned to start the quarry and put it in operation, and the interest rate of $15 \%$ is put on the money loaned annually. The cash flow analysis is shown in (Table 15).

Table 14: Cash flow analysis of the quarry for the period of 10 years.

\begin{tabular}{|c|c|c|c|c|c|}
\hline Year & $\begin{array}{c}\text { Capital Outstanding at the } \\
\text { Beginning of the Year (N) }\end{array}$ & $\begin{array}{c}\text { Interest by End of } \\
\text { Year (15\%) (N) }\end{array}$ & $\begin{array}{c}\text { Total Capital Repayable } \\
\text { by End of Year (N) }\end{array}$ & $\begin{array}{c}\text { Income from Mine } \\
\text { Operation (paid back) (N) }\end{array}$ & Net Cash Flow (N) \\
\hline 1 & $500,000,000$ & $75,000,000$ & $575,000,000$ & $318,795,541$ & $-256,204,459$ \\
\hline 2 & $256,204,459$ & $384,306,692$ & $294,635,128$ & $304,854,544$ & $102,194,416$ \\
\hline 3 & & & & $290,915,344$ & $290,915,344$ \\
\hline 4 & & & & $276,976,144$ & $276,976,144$ \\
\hline 5 & & & & $263,036,944$ & $263,036,944$ \\
\hline 6 & & & & $250,186,744$ & $250,186,744$ \\
\hline
\end{tabular}




\begin{tabular}{|c|l|l|l|l|l|}
\hline 7 & & & & $235,158,909$ & $235,158,909$ \\
\hline 8 & & & & $225,863,959$ & $225,863,959$ \\
\hline 9 & & & & $225,863,959$ & $225,863,959$ \\
\hline 10 & & & & $225,863,959$ & $225,863,959$ \\
\hline
\end{tabular}

Table 15: Present value of the cash flow.

\begin{tabular}{|c|c|c|}
\hline Year & Net Cash Flow & Present Value of Cash Flow (N) \\
\hline 2 & $102,194,416.00$ & $77,273,660.49$ \\
\hline 3 & $290,915,344.00$ & $191,281.560 .90$ \\
\hline 4 & $276,976,144.00$ & $158,362,009.30$ \\
\hline 5 & $263,036,944.00$ & $130,775,849.10$ \\
\hline 6 & $250,186,744.00$ & $108,162,633.60$ \\
\hline 7 & $235,158,909.00$ & $88,404,944.16$ \\
\hline 8 & $225,863,959.00$ & $73,835,320.85$ \\
\hline 9 & $225,863,959.00$ & $64,204,633.78$ \\
\hline 10 & $225,863,959.00$ & $55,830,116.33$ \\
\hline Total & $2,096,060,378.00$ & $948,130,728.50$ \\
\hline
\end{tabular}

Present value of cash flow: The cash flow for the ten years as calculated in (Table 15) using the discount rate of 15\%. Form the formula shown below; the present value of cash in (Table 15) can be calculated from the point where positive value of net cash flow was obtained

$$
\mathrm{P}=\mathrm{F} \cdot \mathrm{V} /(1=\mathrm{i})^{\mathrm{n}}
$$

The present value of the quarry stands at the sum of $£ 948$, $130,728.50$ for the first ten years. If the sum of 500 (million) is borrowed with the interest at $15 \%$ rate.

\section{Need for the project and its relevant to the country and or region}

The Nigerian real estate sector has witnessed high growth rate in recent times with the rise for office and residential spaces. The most prominent need of building stone is as a result of its high compressive strength and durability (among the hardest, dimensional, and structural stones) it can effectively withstand the vagaries of nature. Fine-grained granite is applied in ornamental and monumental work and for inscription purposes. The mineral-rich colours, the hardness and density, enhances its usefulness for several applications. Polished slabs and tiles are employed in countertops, flooring, retaining walls and landscaping around a centre fountain/ pond, staircase and several other design elements (residential and commercial applications). It is also known as the maintenance-free stone. The proposed quarry project will fulfil its end uses in buildings and construction of bridges, paving, monuments, and many other exterior projects. The mining and associated activities in the mineral bearing areas bring about gains in gross domestic product, i.e. even though there is a minor contribution by the proposed project but will add to the gains in G.D.P. (Gross Domestic Product).

\section{Conclusion}

The granite deposit at Gidan Tagwaye, Dutse Local government area of Jigawa state, when quarried for the production of granite has a life time of twenty-five years with the production rate of $72,533,33 \mathrm{~m}^{3}$ per year. The estimated capital cost $\mathrm{N} 456,203,000$ is required sunk capital and the operating cost of N64,049,250 yearly. The project has a payback period of two years before tax. Furthermore, the sum of 500 (million) can be sourced from the commercial bank as loan to finance the project at the rate of $15 \%$. At the end of the payback period, the profit yield at the third year is N4290, 915,344 and the first ten years profit value is at N255, 863.959.

\section{Recommendation}

There has been increase in demand of aggregate stones due to increase in the construction of infrastructures within the country and the state in particular which is owed to development. Based on the data and information obtained from the findings, it will be profitable if these outcrops are quarried to produce aggregate stones. It will be good to know the mineralogical composition of the granite deposit; so as to really known the state and elemental composition to further establish its utilization.

\section{References}

1. Holly W, Sokol S (2007) The role of the extractive sector in expanding economic opportunity. Corporate Social Responsibility Initiative Report MA: Kennedy School of Government, Harvard University, USA. p. 7.

2. Abere DV, Oyatogun GM, Rominiyi AL, Abioye AA, Akinwole IE, et al. (2017) Investigation of physicochemical and mechanical property of UTAN granites for building applications. American Journal of Mining and Metallurgy 4(1): 37-44.

3. Alabi 00, Oyedepo OJ, Abere DV (2017) Investigation of the suitability of fobur granite in Jos, Plateau State, Nigeria for road construction. J Appl Sci Environ Manage 21(4): 709-716.

4. Oyinloye AO (2011) Geology and geotectonic setting of the basement complex rocks in SW Nigeria: Implication on provenance and evolution. Journal of Earth and Environmental Science.

5. Olasehinde A, Bute SI (2014) Report on a feasibility study: A case study of ratcon quarry limited. The Pacific Journal of Science and Technology 15(2): 204-211.

6. Bowers P, Fahram B, Hutchins S, Rose R, Sadtler D, et al. (2012) Acquisition proposal and visibility study of Bev Quarry, Nevada USA.

7. Howard LH (1996) SME Mining Engineering. (2nd edn) Society for Mining, Metallurgy and Exploration, United States of America.

8. Ajibade AC (1982) The origin of the older granite of Nigeria: Some evidence from the Zungeru region, Nigeria. Jour of Min and Geol 19: 223-230.

9. Unuevho CI (2009) Graphic determination of depth to fresh crystalline basement from schlumberger sounding curves: Applicability in Minna, Niger State, Nigeria. Jour of Sci Tech and Maths Education. pp. 191-210. 
10. Nigerian Minerals and Mining Act (2007) Ministry of Mines and Steel Development: Abuja, Nigeria. pp. 33.

11. Nwosu JI (1998) Introduction to surface mining engineering. Anchor Network Publishers Limited Okene, Kogi State, Nigeria.

12. Ameh MB (2017) Valuation of granite outcrops at Mararaban Nitel Kujama in Chikun L G A Kaduna state. NMGS Conference, Kaduna, Nigeria.

13. www.heavyequipment.com/wheelloader.php.
14. (2018) Duwan Company Limited. Namdi Azikuwe Express Way, Kaduna, Nigeria.

15. Nigerian Minerals and Mining Act (2007) Environmental Impact Assessment Regulations, Nigeria.

16. Alabi AA (2011) Geology and environmental impact assessment and benefit of granitic rocks of Minna area, Northwestern Nigeria. Ethiopian Journal of Environmental Studies and Management 4(4): 39-45.

17. Adewale Ajayi (2012) Nigerian Mining Sector, KPMG Advisory Services, Nigeria.

For possible submissions Click below: 